Los documentos de trabajo del Ivie ofrecen un avance de los resultados de las investigaciones económicas en curso, con objeto de generar un proceso de discusión previo a su remisión a las revistas científicas. Al publicar este documento de trabajo, el Ivie no asume responsabilidad sobre su contenido.

Ivie working papers offer in advance the results of economic research under way in order to encourage a discussion process before sending them to scientific journals for their final publication. Ivie's decision to publish this working paper does not imply any responsibility for its content.

La edición y difusión de los documentos de trabajo del Ivie es una actividad subvencionada por la Generalitat Valenciana, Conselleria de Hacienda y Modelo Económico, en el marco del convenio de colaboración para la promoción y consolidación de las actividades de investigación económica básica y aplicada del Ivie.

The editing and dissemination process of Ivie working papers is funded by the Valencian Regional Government's Ministry for Finance and the Economic Model, through the cooperation agreement signed between both institutions to promote and consolidate the Ivie's basic and applied economic research activities.

La Serie EC, coordinada por Matilde Mas, está orientada a la aplicación de distintos instrumentos de análisis al estudio de problemas económicos concretos.

Coordinated by Matilde Mas, the EC Series mainly includes applications of different analytical tools to the study of specific economic problems.

Todos los documentos de trabajo están disponibles de forma gratuita en la web del Ivie http://www.ivie.es, así como las instrucciones para los autores que desean publicar en nuestras series.

Working papers can be downloaded free of charge from the Ivie website http://www.ivie.es, as well as the instructions for authors who are interested in publishing in our series.

Versión: octubre 2019 / Version: October 2019

Edita / Published by:

Instituto Valenciano de Investigaciones Económicas, S.A.

C/ Guardia Civil, 22 esc. $21^{\circ}$ - 46020 Valencia (Spain)

DOI: http://dx.medra.org/10.12842/WPASEC-2019-01 
WP-EC 2019-01

\title{
Private benefits from control block trades in the Spanish stock exchange
}

\author{
Inés Pérez-Soba, Ana R. Martínez-Cañete and Elena Márquez-de-la-Cruz ${ }^{*}$
}

\begin{abstract}
A control block trade can be explained by the expectation of financial gains, shared by all shareholders, or by the expectation of private benefits ( $\mathrm{PB})$, exclusive for the buyer and possibly at the expense of other shareholders' rents. The market for corporate control contributes to social welfare when it improves the efficiency in the allocation of resources. When the purpose of block transaction is $\mathrm{PB}$, social welfare could be damaged as minority shareholders could withdraw from the stock market. So the evaluation of PB will allow to assess the efficiency of the stock market. Using a sample of partial control transactions in the Spanish market over the period 1990-2016, we find that, in median, PB are null. Their variability is explained in a significant way by the controlling position of the buyers in the target firm after the transaction, the size of control of the "rival" insider and to the size of the firm.
\end{abstract}

Keywords: private benefits, block trades, ownership structure, partial control acquisitions, control block premium.

JEL classification: G12, G34, G38.

\section{Resumen}

La compra de un bloque de control puede explicarse por los beneficios financieros esperados, compartidos por todos los accionistas, o por la expectativa de beneficios privados (BP), exclusivos para el comprador y obtenidos posiblemente a expensas de las rentas de los demás accionistas. El mercado de control societario contribuye al bienestar social cuando mejorar la eficiencia en la asignación de recursos. Cuando el objetivo de la compra del bloque son los BP, el bienestar social podría verse perjudicado ya que los accionistas minoritarios podrían retirarse del mercado de valores. Por lo tanto, la medición de los BP permitirá evaluar la eficiencia de la bolsa. Utilizando una muestra de transacciones de control parcial en el mercado español durante el período 1990-2016, encontramos que, en mediana, el BP es nulo. Su variabilidad se explica de forma significativa por la posición de control que alcanza el comprador tras la operación, el tamaño del control que posee el accionista "rival" y el tamaño de la empresa.

Palabras clave: beneficios privados, operaciones en el mercado de bloques, estructura accionarial, adquisiciones de control parcial, prima del bloque de control.

Clasificación JEL: G12, G34, G38.

\footnotetext{
* Universidad Complutense de Madrid.

Correspondence to: I. Pérez-Soba. Universidad Complutense de Madrid, Applied Economics Department, Campus de Somosaguas, 28223 Madrid. Tel.: +34 913942527 / Fax: +34 913942582 / E-mail: iperezso@ucm.es.

Acknowledgements: The authors would like to thank Vicente Salas for his time, comments and helpful suggestions and Domingo García Coto and Maria Paz Alonso (BME) for their support in the process of searching for the data.

This work was supported by the Ministerio de Economía y Competitividad under Grant ECO2015-67035-P; and Ministerio de Economía y Competitividad under Grant ECO2016- 77843.
} 


\section{Introduction}

The market for corporate control comprises not only full acquisitions of control, via takeover bids or mergers, but partial acquisitions of control as well. A common way to deal the partial control of a target firm is by means of block trades. ${ }^{1}$ A block trade is a single transaction of a relatively great number of shares of one firm that is made under special conditions, as the price is arranged between two parties, so they are usually carried out in specific markets. ${ }^{2}$ When the block allows the buyer to have a certain degree of decision over the firm policy, this block would be a control block.

The trade of blocks can be explained by the expectation of financial gains. These gains can come because an active buyer has achieved a control position in the firm, generally due to the size of its block, and implements a more profitable strategy. ${ }^{3}$ These benefits are shared with the rest of shareholders and are usually proportionate to the shareholder's ownership fraction. ${ }^{4}$

These trades can also be caused by the expectation of other kind of benefits that can only be enjoyed by the owner of a control block, that is, someone who has decisionmaking power thanks to the votes the block gives. This is the reason why they are called private benefits (or control rents). The measure of these benefits is important as they could consist of consuming firm resources at the expense of the rents of other shareholders (excessive salaries, payments in kind, transfer prices below market prices

\footnotetext{
${ }^{1}$ The market for partial control acquisitions is defined as the market for block purchases made by a buyer who is an active investor that looks essentially for exercising explicitly a certain degree of control, but not a full control, in order to be influential in the corporate decisions of the target firm. The term market for partial corporate control was first introduced by Bethel et al. (1998).

${ }^{2}$ In many developed Stock Markets, such as the USA Exchanges, Euronext, the SWX Swiss Exchanges, the German Exchanges or the Spanish Exchanges, there exists this kind of markets for large trades. Some related literature about its functioning can be found in Mikkelson and Partch (1985), Demarchi and Foucault (1998) or Pérez-Soba et al. (2018).

${ }^{3}$ Take into account that financial gains can also be achieved by passive buyers of block trades, such as institutional investors many times, that do not decide directly on firm policy. They just "vote with their feet”.

${ }^{4}$ In Shleifer and Vishny (1986) it is possible to find a classical reference for this kind of benefits.
} 
...) that can hardly prevent it from happening. ${ }^{5}$ The amount of this type of private benefits (PB), when detected by the market, could have a negative impact on the raise of capital funds for the firm, as minority shareholders would avoid lending money to those firms that misuse the funds. So, given that the market for (partial) corporate control contributes to social welfare only if it contributes to improve the efficiency in the allocation of resources, the generalisation of transactions of control block shares for the purpose of rent extraction will damage social welfare, because the expectation of expropriation of rents will keep minority shareholders out of the stock market, so the efficiency prices will be distorted. Thus, the estimation of the private benefits from trades of blocks would be justified because depending on the results it will be possible to make an assessment of the efficiency of the stock market and its potential to raise financial resources.

This paper deals with this issue focusing in the Spanish stock market. This market is characterized by a high degree of ownership concentration, a feature that is also common in other European stock exchanges, so it is usual to find large shareholders selling their blocks, or a part of them, that may imply certain control in the firm.

The exhaustive search of control block trades and the method used to construct the sample are ones of the main contributions of this paper. While most of the empirical literature use to assume that blocks above a given size involve control and, therefore, the measure of the premium for the buyer would be an estimation of PB (Barclays \& Holderness, 1989; Dyck \& Zingales, 2004; Massari et al. 2006; Gregoric and Vespro 2009 or Alburquerque \& Schroth, 2010, among others), we look for block trades that give to the buyer an unambiguous control position in the acquired firm. The reason is that we think that taking as the criterion for measuring PB that the block sizes are above

\footnotetext{
${ }^{5}$ There are also non-monetary benefits that could not reduce the minority shareholders' wealth, such as the satisfaction of the firm's founder resulting from keeping its position as the principal shareholder.
} 
a certain size could be including in the sample some transactions that are mere financial operations and, in consequence, this criterion could be biasing the size of PB since, by definition, PB can only be enjoyed by control owners.

In order to avoid this kind of bias we only include in the sample those transactions disclosed as significant that give the possibility of enjoying PB because of the control position that they provide in the target firm. And this possibility may come from a relative large size of a block, when the buyer has no an initial position in the shareholding of the target firm; a small size, when the buyer is a significant shareholder in the target firm before buying the block or (and) from having the opportunity of nominating a candidate for the Board of Directors of the target firm. ${ }^{6}$ So the variable to measure control is the final stake of the buyer instead of the size of the block purchased, another contribution of this paper.

This new approach has a number of advantages. On the one hand, it allows us to disentangle the reasons that are behind block purchases from the viewpoint of the buyer since, as abovementioned, in many papers financial or strategic interests and controlling aims are mixed under the label "block transaction" (see Table 1). On the other hand, as we include in the analysis smaller sizes of blocks than those that are usually studied and that can give marginal control, we are able to capture their marginal value in relation to PB. $^{7}$

Once we have the sample, we measure PB and test different hypotheses put forward by theoretical and empirical literature about the effect that some variables (related to the transaction, the buyer and the firm) may have in explaining the cross-sectional variability of PBs. These are additional contributions since, as far as we know, this is

\footnotetext{
${ }^{6}$ This last criterion is supported by Berle (1958), OECD (2009) or Park et al. (2008), among others.

${ }^{7}$ In this manner, we take into account the increase in control that the block gives to a previous stake instead of considering both variables in a separated way.
} 
the first study that assesses specifically the PB in the Spanish market and seeks to explain its size according to corporate governance variables.

Our main results show that, on median, there are not PB for the buyer. This does not mean that there are not high positive PB but it seems that they are offset by high negative $\mathrm{PB}$, which also exist. The distribution of $\mathrm{PB}$ shows a dispersion that can be explained in a significant way by the controlling position of the buyer in the target firm after the transaction and the size of control of the "rival" insider, so the control structure of the firm affects the extraction of PB. In a lesser extent, it is also found significant the size of the firm.

The rest of the paper is organized as follows: in the next section, there is a brief theoretical and empirical review of the basic ideas and results that appear in the Corporate Governance literature about PB that allow us to put forward several hypotheses. Section 3 is dedicated to the empirical analysis: first, we explain how PB are calculated in our study and how the sample has been constructed. Besides, some descriptive statistics of PBs and the control block transactions are shown. Secondly, we show the variables that are used to the test the hypotheses and could explain the variability of these control rents. Thirdly, we present the results of the regressions. Finally, in Section 4, we point out the main conclusions and policy implications.

\section{Private benefits in economic literature: theoretical review and empirical results}

\subsection{Theoretical background and hypotheses proposal}

The recognition by the literature of the existence of PB within large corporations can already be guessed in the contribution of Berle and Means (1932), who pointed out that the separation of ownership (shareholders) and control (managers) in large listed 
companies gives the managers the opportunity and the incentive to misuse their position. This idea is later formalized under the agency theory (agency problem type I) where the consumption of $\mathrm{PB}$ appear under the conflict between managers and shareholders. Thus, Fama and Jensen (1983), Demsetz and Lehn (1985) and, especially, Jensen and Meckling (1976), when studying the effect that managers' stakes in the firm have on their decision-making, point out that the higher benefits that they enjoy, compared to the financial benefits of their holdings, are due to the existence of other source of benefits, only enjoyed by them. These private benefits, according to Grossman and Hart (1980), are necessary to incentive raiders to buy poorly managed companies in the market for corporate control, since financial benefits that they could obtain are expropriated by free riders in their model. Therefore, PB would be the only way to get a return for the buyer when it has not an initial stake in the target firm.

At a later stage, the conflict over the personal use of firm's resources is focused on controlling shareholders and their expropriation of minority shareholders, under the agency problem type II (Shleifer and Vishny, 1997). This is especially important in those countries where ownership concentration prevails in corporations, as it is the case of most European economies, including Spain. According to Bebchuk (1994), who focus on large shareholders instead of managers, PB can come from excessively high salaries or/and perquisites to merely psychological rewards which in this latter case could have positive effects for both the buyer and the firm. ${ }^{8}$ So, in theory the existence of PB do not always indicate bad news to the shareholders.

But, in the real world, noticeable PB mean negative news to the firm, and their amounts are linked to poor protection of shareholders (Nenova, 2003) which could

\footnotetext{
8 Those PB that reduce shareholders' wealth, that is, that are consumed at the expense of the rest of shareholders are considered “detrimental”. They are also called “tunnelling” (Johnson et al., 2000).
} 
imply the withdrawal of minority shareholders from the Stock Market. ${ }^{9}$ In this line, Nenova (2003) stresses the importance of limiting the control protecting Corporate Charter provisions. Other solutions are raised in Dyck and Zingales (2004) who focus on legal (e.g. tax compliance) and institutional variables (e.g. public opinion pressure) to help curb PB.

Regarding the amount of PB, it is analysed in theoretical models that look for the optimum size of a block for an acquirer. This is the case of Burkart et al. (1998) who, under the assumption that the extraction of PB is inefficient, point out that the optimum size is one that gives just enough control to enjoy PB without paying for them so much. Thus, from such an optimum size of control block onward, the more equity the acquirer buys, the more private benefit it pays at expense of its financial benefits (less dividends or lower stock prices). That is, they think that PB function is a strictly increasing and concave function in relation to the size of control block. This means a nonlinear relationship between the size of control and the size of PB.

Hypothesis 1:

The higher is the stake of the buyer, the more PB consumption till a maximum size of the stake where the buyer would have negative incentives to consume more PB and, in consequence, the amount of consumption will decrease.

When analyzing, in a later work, which factors could explain the size of PB, Burkart et al. (2000) point out the importance of taking into account the bargaining power of the seller (the controlling shareholder) and the buyer when PB are distributed among them, which is also stressed in Dyck and Zingales (2004). Relatively low earnings of the target firm give less power of negotiation to the seller. Besides, poor

\footnotetext{
${ }^{9}$ One of the solutions to reconcile the incentives that PB give and the avoidance of excessive control rents points to self-regulation in form of Codes of Best Practices. In fact one of the reasons why these codes emerged was the perception that the board of directors and managers consume disproportionate resources of the firm to their own advantage.
} 
performance in the target firm might imply higher monitoring costs (Bolton and von Thadden, 1998; Burkart et al., 2000). Therefore, when the firm is poorly run or in the bad state of nature, the block price would be expected to be sold at discount.

Hypothesis 2: The bargaining power of the seller and buyer will be related to the economic or the financial situation of the firm in such a way that the size of PB consumption will be lower the worse is the situation, since the lesser power has the seller and the higher are the cost of monitoring for the buyer.

Another approach to the size of PB focuses on the distribution of power among controlling shareholders within the target firm. In this line, the theoretical model of Bennedsen and Wolfenzon (2000) or Gomes and Novaes (2001) put forward that the dilution of power among multiple large shareholders could restrain the diversion of funds, given that the initial (main) owner should require the consent of the other large shareholders to enjoy PB. Going one step forward, other studies focus on the differences in the size of stakes of control of multiple large shareholders. The idea is that similar sizes may enhance the contestability of control, and then the competition among owners to extract $\mathrm{PB}$, such that the higher is the contestability, the lower will be the bargaining power in hands of the largest shareholder and the lower should be the PB extraction from minority shareholders. Thus, Bloch and Hege (2001) and Maury and Pajuste (2005) find that contestability will be higher where the difference in the stakes (or in the voting power) of the larger shareholders is smaller and the size of their stakes are small as well.

Hypothesis 3: The size of PB will be higher, the higher is the difference in the size of stakes of the controlling shareholders.

Continuing with the buyer, as it has been proved to be significant its identity, specifically whether the buyer is a natural person or a family. In corporate governance 
literature some authors consider individuals or families more prone to use the opportunities of enjoying PB (Barclay and Holderness, 1989; Volpin, 2002; Barak and Lauterbach, 2011) compared to corporations.

However, other authors, such as Arregle et al. (2007), consider that family members might expropriate less benefits as they would care more about the companies founded by them (they might even be considered a part of their identity), so their main interest would not be basically pecuniary (Corbetta and Salvato, 2004). Besides, they usually have a relatively high weight of their portfolio invested in the firm so, as long as they increase their stake in the firm and they consume more private benefits, the will pay more for them. So the expected sign of the relationship would depend on the strength of each of these opposite effects.

Hypothesis 4a: The size of PB will be higher when the buyer is a family or a natural person.

Hypothesis 4b: The size of PB will not be affected when the buyer is a family or a natural person, since the positive effect explained in hypothesis 4a might be offset by the negative one due to the lower agency problem that this kind of buyer could cause.

Finally, PB has also been related to the size of the firm. Yermack (2006) points out that it is more difficult to monitor larger firms, so it is easier that agency problems arise and, therefore, to consume control rents. But, on the other hand, these firms are more supervised by regulators, media and analysts (Barak and Lauterbach, 2011) so this would offset the previous positive effect.

Hypothesis 5a: The size of the firm affects the consumption of PB, such that the larger is the firm, the easier is to consume PB, so the larger will be the size of this benefits. Hypothesis 5b: The size of the firm do not affect the consumption of private benefits, since the positive effect that the difficulty of monitoring larger firms has on the size of 
$\mathrm{PB}$ is compensated by the negative one that the higher external supervision of this kind of firms has.

We will test these hypotheses in the further empirical analysis for the Spanish market.

\subsection{Empirical literature}

How can PB be measured? As Dyck and Zingales (2004) indicate, these benefits are not easy to quantify not only because sometimes they are just psychological benefits, but because its very nature as well: if they were easy to measure, the rest of shareholders that do not enjoy, but, on the contrary, pay them, would claim them in a court. Nonetheless, we can find in the empirical literature two ways of estimating PB:

(I) The pioneering work in this literature is Barclay and Holderness (1989) who estimate this benefit by calculating the difference between the price per share paid by the buyer for the control block and the market price after the transaction takes place divided into that market price. This method is assuming that the block price is including not only the expected security benefits of the block (cash flows) but the PB or rents that the buyer would consume once it has the control of the target firm. This measure is, therefore, a rate of return for the buyer. Likewise, they consider another measure of PB multiplying this return by the size of the block in order to relate PB to the size of equity of the firm.

Some later papers calculate the rate of return (PB) by means of the event study methodology, using the market model to estimate the expected return of the target firm as if the block transaction had not happened and, then, comparing it to the one observed in the market after the block transaction. These methods have been used by several authors to find out PB, either at a national level or at a cross-country one. 
(II) The voting premium estimation: it is suggested by Zingales (1995) and it relates PB to the difference between the market prices of voting and non-voting shares, what is called “dual-class premium” (Carvalhal and Subrahmanyam, 2007).

The first method is the most frequently used by researchers since in many countries it is not very extended the issue of non-voting shares. These papers are usually based on samples which deal with block transactions of a certain size, generally from five per cent to the threshold of a legal tender offer. Table 1 summarizes the main features of several studies according to the method of calculating PB.

As it can be seen, there is a wide range of values for PB, either in country studies (e.g. in the USA, depending on the period and the method of estimation, the values are quite different) or in cross-countries ones. But, in general terms, it seems that the buyers, on average, in almost all the countries analysed, earn a positive rent when buying a block that is assumed that gives them the opportunity of deciding in the target firm. The exception is Japan which shows a negative premium.

In our paper, the block-premium approach is followed, as in the Spanish economy there are very few listed firms which has differential voting rights shares.

In the next section, once the sample is built according to a control criterion instead of a block size one, we will compare our results with the two studies that measure the PB for Spain (Fernández-Blanco and García, 2000; Dyck and Zingales, 2004). To do this, we will try, with our sample, to follow their criteria or/and use their sample period. In this way we will evaluate whether there are differences in the value of PB for Spain due to the change of criteria to make the sample. 
Table 1

\begin{tabular}{|c|c|c|c|c|}
\hline & N. of observations & Country & Time period & Results on average (median) \\
\hline \multicolumn{5}{|c|}{ Block premium method } \\
\hline Barclays \& Holderness (1989) & 63 block transactions ( $>5 \%$ equity) & USA & 1978-1982 & $20 \%(16 \%)$ \\
\hline Alburquerque \& Schroth (2010) & 120 block transactions ( $>10 \%$ equity) & USA & 1990-2006 & $3 \%$ \\
\hline Massari, Monge \& Zanetti (2006) & 7 "pure" block trades & Italy & 1993-2003 & $8.07 \%(2.91 \%)$ \\
\hline Fernández-Blanco \& García (2000) & 378 block transactions & Spain & $1987-1995$ & $0 \%$ \\
\hline Barak and Lauterbach (2011) & 54 block transactions firms & Israel & 1993-2005 & $0.3 \%$ \\
\hline Weifeng \& Zhaoguo \& Shasha (2008) & 112 control transactions of non-tradable stocks & China & $1997-2004$ & $18.52 \%(11.37 \%)$ \\
\hline Gregoric \& Vespro (2009) & 31 block transactions ( $5 \%-25 \%$ voting rights) & Slovenia & $2000-2001$ & $47 \%(21 \%)$ \\
\hline Rydqvist (1992) & 62 firms & Sweden & $1980 \mathrm{~s}$ & $15 \%$ \\
\hline Muravyev et al. (2014) & 190 firms & Russia & 1998-2009 & $113 \%$ \\
\hline Nenova (2003) & 661 firms & 18 countries & 1997 & $\begin{array}{l}\text { From } 0 \% \text { (Denmark) to } 36 \% \\
\text { (Mexico) }\end{array}$ \\
\hline Doidge (2004) & 745 firms & 20 countries & 1994-2004 & From $0.8 \%$ (Mexico) to $67 \%$ (Korea) \\
\hline
\end{tabular}




\section{Empirical analysis}

\subsection{Private benefits premium calculation}

As most of the empirical studies abovementioned, we have followed the block premium method proposed in the seminal work of Barclay and Holderness (1989). Thus, we calculate the private benefit premium as a rate of return defined as the difference between the price per share paid in the block transaction (which is determined by the buyer and the seller and not by the market) that implies control and the market price after the announcement of the transaction, divided by the market price after the announcement of the transaction.

As these authors point out, the sale price would reflect the buyer's willingness to pay. Since we are trying to isolate only those transactions that transfer control to some extent, we assume that in this price it is included the benefits that control would provide. ${ }^{10}$

An important question raising by the works of Hoffmeister and Dyl (1981) or Walkling (1985) is which relevant date has to be considered as the day after the announcement. There are strong arguments for choosing such a day as the day when the first information concerning the transaction becomes public. Following this approach, we have determined that date in our calculations by reviewing: a) the Spanish Security Exchange Commission (CNMV) official registry of Relevant Facts; b) the business press, since in many cases the information becomes public through the press before the announcement is officially registered with the CNMV and c) the Madrid, Barcelona, Bilbao and Valencia Stock Exchange Market Bulletins, where the transaction is published. The earliest date is chosen and then we have taken the market price one working day after the announcement of the deal $(t+1)$. In this way we try to incorporate the

\footnotetext{
${ }^{10}$ As Dyck and Zingales (2004) show, as long as the value of the firm is the same for the seller and the buyer, this way of estimating private benefits will be proper whether the market is perfectly competitive or not.
} 
impact of the transaction information on the market prices in order to take out from the block price the return that is due to expected cash flows under the new controlling shareholder. As standard in the literature, these premiums are adjusted by the market return to control for news that could have affected the stock prices; to do so, firstly, we have estimated the "normal" return of each of the target firms in our sample using the market model:

$$
R_{i, t}=\alpha_{i}+\beta_{i} R_{M, t}+\varepsilon_{i, t}, i=1, \ldots, N
$$

We have used monthly returns for each firm $\left(R_{i, t}\right)$ and the Madrid Stock Exchange General Index as a proxy for the market return $\left(R_{M, t}\right)$ for the whole sample period to estimate the alphas and betas for each firm. After that, we calculate the "normal" return between $t$ and $t+1$ as follows:

$$
R_{i, t, t+1}^{*}=\alpha_{i}+\beta_{i} R_{M, t, t+1}
$$

Then, the private benefit adjusted by the market is calculated in the following way:

$$
R_{i, t}^{\mathrm{PB}}=\frac{P_{B_{i, t}}-P_{i, t+1}}{P_{i, t+1}}-R_{i, t, t+1}^{*}
$$

where $P_{B_{i, t}}$ is the block price and $P_{i, t+1}$ is the market price 1 day after the first announcement of the deal, $t$.

In order to have the value of $\mathrm{PB}$ as a percentage of the value of equity, as Barclay and Holderness (1989), Dyck and Zingales (2004) and other authors do, we multiply $R_{i, t}^{\mathrm{PB}}$ by the size of the control block (as \% of the equity). This private benefits equity adjusted premium is our proxy of $\mathrm{PB}$ and it will be the dependent variable in the following empirical analysis for the Spanish case. 


\subsection{Sample}

The sample we use has been constructed taking the register of Relevant Facts that the Spanish Security Exchange Commission (CNMV) publishes in its web page as the original source of information. ${ }^{11}$ We have analyzed more than 4,400 registers related to deals involving the transmission of holdings and block trades for the period 1991-2016. When the transactions are included in that register it is assumed that all of them could affect the market price of the firms involved and, for this reason, these firms should report to the CNMV. The number of block transactions is, however, much smaller (around $12 \%$ of the registers) since for the most part the content of the information is not directly related to the data we look to construct the sample (so we discard capital increases, IPOs, debt purchases and so on) and it is also frequently found that more than one register is recorded for one transaction. ${ }^{12}$ Besides, we take into account that the transaction is not merely announced, but completed as well.

Once we have identified the registers about actual block transactions, we have selected those transactions made in the stock exchange, that is, those that must have involved a listed target firm in the Spanish market at the time of the transaction. We find that around $20 \%$ of the registers are related to firms that are either unlisted or listed but not in the Spanish Stock Markets, so we have to discard them in order to obtain the market prices to calculate the $\mathrm{PB}$.

Then, we have selected those block transactions that may imply control but not trigger a tender offer within the following year. These block transaction must meet that the buyer has achieved or reinforced a controlling position in the target firm after the transaction, either by means of being among the three largest shareholders or by

\footnotetext{
${ }^{11}$ Fernández-Blanco and García (2000) use the press announcements of the block trades below 25\% of the equity to make up their sample of significant transactions.

${ }^{12}$ An extreme case is Iberdrola; we have computed more than 150 published relevant facts referring to the same deal. This example can explain the reason why our final sample is significantly smaller than the consulted registers related to block transactions.
} 
achieving or adding a seat in the Board of Directors. In order to identify these transactions, we checked the ownership structure before and after the transaction and the changes in the Board of Directors using the following sources: the register of Relevant Facts of the CNMV (in this stage we used the register of Boards of Director), the Annual Corporate Governance reports, the Annual Reports and the financial press. We have analyzed these sources looking for changes in the Board of Directors related to the transactions during a one year period following the operation, checking that the (increase in) size of the block of the buyer that obtained a seat on the Board is similar to the size of the control transaction. To make this analysis we need to know the buyer's identity and the shareholder structure. These essential requirements caused around 32\% of the operations to be eliminated from the sample. Of the rest, around half of the transactions might be motivated by financial purposes since they do not meet the requirements we have proposed to consider a transaction that gives or reinforce a controlling position.

Other requirements that the transactions have to meet are that they do not involve the Company's own shares (treasury stock) and they are not from target financial institutions or insurance companies. ${ }^{13}$

Finally, the price per share of the block must be identifiable. Identifiable means, firstly, that it is possible to know the price (we consulted the Relevant Facts Register, the Stock Market Bulletin and the financial press) and, secondly, that it is possible to calculate the transaction price objectively. When non-cash payments (derivatives, other

\footnotetext{
${ }^{13}$ There are several reasons for excluding financial firms from the sample: financial firms are subject to especial accounting standards and risk factors, and they are more heavily regulated than non financial sectors as well. In fact, there exists in Spain, since 2009, a specific law for significant holdings in supervised financial firms (Directive 2007/44/EC of the European Parliament and of the Council of 5 September 2007). The lost of these transactions involves 10 medium-size banks. The other requirements imply to exclude around $2 \%$ of the registers.
} 
financial assets or intricate means of payment) were used the transactions were excluded (around 12 per cent of the transactions).

In this process we have also removed around 6 per cent of the transactions because of the lack of data for the further analysis as well as a small number of transactions (0.5\%) that come from the same broken block, of which we have only included those transactions that are bought on different days, have different type of buyer, different selling price, and different size in order not to duplicate the operation's information.

Hence, we have not made up the sample starting from a specific size of the block, as other studies do. The limits are set depending on the "boundaries" that a market for partial corporate control could have, that is, the lower bound is an operation that could have an effect on the firm's price, which could come from a marginal purchase of a smaller size block than is normally considered. The upper bound is a significant block that could trigger a legal tender offer. ${ }^{14}$

As a result of applying all these requirements, our sample is made up of 73 operations, out of which 27 show positive PB and 46 show negative ones. The main descriptive statistics of private benefit premiums (calculated as described in Section 3.1) for the sample of the 73 control block transactions (obtained as described in this section) are shown in Tables 2 and 3.

Table 2 shows the distribution of the deals between positive and negative $\mathrm{PB}$ in the sample: 37 per cent are transactions with positive PB while in 63 per cent of the deals the benefits are negative. When analyzing Table 2 some results appear especially noteworthy: (i) the small size of the average and median PB premiums in the whole

\footnotetext{
${ }^{14}$ In Spain the "upper bound" has been modified because of the change of tender offers law in 2007 that, in general terms, varies the threshold from $25 \%$ to $30 \%$ of the target's equity. So the use of a qualitative criterion to analyse the transactions, instead of a quantitative one (\% of equity), avoids a change in the criterion (size of the block) in order to be included in the sample.
} 
sample and their negative signs; (ii) the similar absolute values of the maximum and minimum premiums; (iii) it can not be rejected that the median is zero in any case (either for the positive, negative or for the whole sample). ${ }^{15}$

Table 2

Private benefits: positive and negative premiums

Main statistics of the size of private benefits, calculated as a percentage of the equity (PB)

\begin{tabular}{l|c|c|c|}
\hline \hline \multicolumn{2}{c}{ PB } & POSITIVE PB & NEGATIVE PB \\
\hline \hline Mean & -0.0010 & 0.0202 & -0.0135 \\
Median & -0.00039 & 0.00361 & -0.0020 \\
Maximum & 0.1442 & 0.1442 & $-5.28 \mathrm{E}-07$ \\
Minimum & -0.1334 & 0.0002 & -0.1334 \\
Std. Dev. & 0.0350 & 0.0387 & 0.0258 \\
Observations & 73 & $27(37 \%$ of total $)$ & $46(63 \%$ of total $)$ \\
\hline \hline
\end{tabular}

Therefore, this descriptive analysis shows that, in the case of the Spanish stock market, private benefits (as a percentage of the equity) are zero in median. This result contrasts with the positive ones ( 4 per cent the mean and 2 per cent the median) obtained in Dyck and Zingales (2004). These authors study the Spanish market only considering five control block transactions which are larger than or equal to 10 per cent of the target's equity. To make more comparable these results with ours, we have calculate the average and median of those transactions of our sample that meet the criteria set by Dyck and Zingales of dealing a block size higher than or equal to $10 \%$ (27 transactions). We can not reject again that median values of PB of these transactions in our sample are statistically equal to zero. As the distribution is not normal we can not test whether the mean value (0.0026) is equal to zero.

Other study for the Spanish market is the one by Fernández-Blanco and García (2000) whose aim is to measure the market reaction at the press announcements of

\footnotetext{
${ }^{15}$ We use the Wilconxon test for the median because the PBEs do not follow a normal distribution and, so, standard tests for the mean can not be applied.
} 
block transactions for the period 1987-1995 by means of an event study. It is assumed that when a transaction appears in press indicates that it is a significant transaction. From a sample of 378 block transactions, most of them of blocks sizes lower than $5 \%$ of the equity, they find that the mean premium in the window [0;5] is a statistically significant zero per cent. This means that the response of market returns over five days after the announcements of block transactions $(t=+5$, being the announcement date $t=0)$ compared to the ones that would have been without that transaction is negligible. To compare this result with ours, we calculate the average premiums in our sample for their sample period (1987-1995) and we find that they are also zero per cent.

In view of the comparison of our results with these two studies, we can conclude that: (i) It seems that to refine the criteria to construct the sample allows negative premiums to emerge and show that control block transactions are not necessarily linked to (explicit) rent extractions in the Spanish market, as in Dyck and Zingales (2004). (ii) It seems that the specific studies for countries sometimes allow a more accurate measure of the domestic variables.

\subsection{Variables linked to private benefits}

As seen previously, there is no evidence of significant private benefits on average and median in the Spanish listed firms. Nevertheless there exists some degree of variability in $\mathrm{PB}$ that could be explained by several variables which proxy the hypotheses put forward previously, that are related to some characteristics of the target firm, the buyer and the deal.

Some descriptive statistics about that variables are shown in Table 3. Regarding the characteristics of the target firm, larger firms and firms with higher earnings per share are more frequently associated to positive PB. In relation to the controlling shareholders, it is remarkable the high stake of the largest shareholder who is not the buyer when PB are 
positive (33\% of equity on average) and the higher dispersion of that stake. The buyer, however, has a much lower stake before the transaction (4 per cent on average) being this average size similar for positive and negative PB deals. Nevertheless, the variability of the buyer's toehold is higher when the deal gives negative benefits. Following with the buyer identity, it can be seen that the buyer is a natural person in a small number of the transactions, no matter what sign, positive or negative, the PB have, although they have more weight in those deals linked to positive PB than to negative ones.

Table 3 also shows that the average block size of the total sample is around 9 per cent, 10 per cent for blocks that give positive benefits and around 8 per cent for those deals with negative $\mathrm{PB}$, so there are no significant differences in the average size depending on the sign of PB. 
Table 3

Variables linked to PB: descriptive statistics

CHARACTERISTICS OF

CHARACTERISTICS OF

CHARACTERISTICS

THE TARGET FIRM*

THE BUYER**

OF THE DEAL*

\begin{tabular}{|c|c|c|c|c|c|c|}
\hline & $\begin{array}{c}\text { Firm Size } \\
\text { (billion of euros) }\end{array}$ & Earnings per share $t-1$ & $\begin{array}{l}\text { Firm control structure } \\
\text { (\% of control of the largest } \\
\text { shareholder who is not the buyer) }\end{array}$ & Previous Stake & $\begin{array}{l}\text { It's a natural } \\
\text { person }\end{array}$ & Block size \\
\hline A. ALL TRANSACTIONS & $3.2(4.8)$ & $7.55(42.3)$ & $22 \%(15 \%)$ & $4 \%(10 \%)$ & $8[11 \%]$ & $9 \%(8 \%)$ \\
\hline $\begin{array}{l}\text { B. POSITIVE PRIVATE } \\
\text { BENEFITS }\end{array}$ & $3.8(5.7)$ & $17.61(65.04)$ & $33 \%(17 \%)$ & $5 \%(8 \%)$ & $4[15 \%]$ & $10 \%(8.5 \%)$ \\
\hline $\begin{array}{l}\text { C. NEGATIVE PRIVATE } \\
\text { BENEFITS }\end{array}$ & $2.8(4.1)$ & $0.43(0.45)$ & $18 \%(13 \%)$ & $4 \%(11 \%)$ & $4[9 \%]$ & $8 \%(7 \%)$ \\
\hline
\end{tabular}

Notes: the firm size is the average target firm's market value at the end of the previous year calculated as the number of outstanding shares by the close market price the last day of the previous year; earnings per share $\mathrm{t}-1$ is the net income of the target firm minus the preferred dividends of the previous year divided into the outstanding common shares at the end $\mathrm{t}-1$; the \% of control of the largest shareholder who is not the buyer is the stake that has the main shareholder or the second one (when the largest is the buyer) in the target firm, in \% of equity; previous stake is the average previous stake of the buyer in the target firm; the buyer is a natural person includes the number of deals in which the buyer is a natural person; block size measures the number of shares in block over the number of shares in equity.

* Standard deviation inside brackets

$* * \%$ of total deals inside square brackets 
The definition of the variables used in the regression analysis to explain the variability of PB are shown in Table 4. Beginning with the buyer, its relative control in the target firm is measured by its final stake. The reason is that, given that we are including in the sample very small sizes of blocks, in order to capture the marginal effect of a block in a controlling position, instead of using the size of the block we prefer to use the variable the size of control of the buyer, that adds the previous stake in the target firm of the buyer to the block acquired in the transaction; then it is divided by the amount of shares of the equity. To capture the possible nonlinearity between this variable and the size of the $\mathrm{PB}$, we use a quadratic function to take into account the decreasing effect of the control on the size of PB once a specific size of control is reached (hypothesis 1).

Besides, to capture the possibility of competition or collusion between the buyer and other large shareholders (hypothesis 3) we include a variable that measures the stake of a large controller in the firm, the largest one when the buyer is not, or the second one when the buyer is the largest one. With these two previous variables we try to test the importance of the control structure of the target firm in the control rents extraction. ${ }^{16}$

Continuing with the buyer, it has been proved to be significant its identity, specifically whether the buyer is a natural person (Barclay and Holderness, 1989; Volpin, 2002; Barak and Lauterbach, 2011; Arregle et al., 2007; Corbetta and Salvato, 2004; Isakov and Weisskopf, 2014) compared to corporations. So we test its influence on the extraction of PB (hypotheses 4a and $4 \mathrm{~b}$ ) by means of a dummy variable, which equals 1 when the buyer is a natural person or a family and 0 otherwise.

\footnotetext{
${ }^{16}$ The F-statistic is significant for the quadratic relationship between the buyer's stake and PB while it is not for the relationship between the "other" larger shareholder's stake and PB. In the latter it is only significant for a linear relationship.
} 
In addition, the performance of the target firm seems to be important to explain the variability of $\mathrm{PB}$ sizes (hypothesis 2) due to the restriction that the size of the earnings should entail both to the extraction of $\mathrm{PB}$ and the power of negotiation between the buyer and the seller (poor performance in the target firm gives less power of negotiation to the seller, as Bolton and von Thadden, 1998 or Burkart et al., 2000, state). We use the variable earnings per share to measure the performance of the firm.

Finally, in relation to the size of the firm (hypothesis 5), to test which of the two possible effects on the size of PBs, the difficulty of supervising larger firms by the insiders (managers and directors) or, on the contrary, the higher degree of supervision that outsiders (regulators, media and analyst) prevails, we use the market value of the firm as a proxy.

Industries's dummies are included in the regression to control for sectorial effect on the size of PB.

Table 4 shows the definition of the above mentioned variables and the data sources.

Table 4. Definition and source of data of independent variables used in the Ordinary Least Squares Regression

\begin{tabular}{|l|l|l|}
\hline \multicolumn{1}{|c|}{ Variable } & \multicolumn{1}{|c|}{ Definition } & Data source \\
\hline $\begin{array}{l}\text { The relative size of } \\
\text { control of the buyer }\end{array}$ & $\begin{array}{l}\text { Number of shares (block + previous stake) / Equity } \\
\text { (in number of shares) }\end{array}$ & $\begin{array}{l}\text { CNMV, Stock } \\
\text { Market Bulletin, } \\
\text { Annual Reports }\end{array}$ \\
\hline $\begin{array}{l}\text { The relative size of } \\
\text { control of the largest } \\
\text { shareholder, excluding } \\
\text { the buyer }\end{array}$ & $\begin{array}{l}\text { Number of shares of this kind of shareholder / } \\
\text { Equity (in number of shares) }\end{array}$ & $\begin{array}{l}\text { CNMV, Stock } \\
\text { Market Bulletin, } \\
\text { Annual Reports }\end{array}$ \\
\hline Performance & $\begin{array}{l}\text { Earnings per share (in euros) = EPSt-1 = (net } \\
\text { income - preferred dividends) t-1/ outstanding } \\
\text { common shares end t-1 }\end{array}$ & Datastream \\
\hline $\begin{array}{l}\text { Identity of the buyer: } \\
\text { natural person }\end{array}$ & $\begin{array}{l}\text { Dummy variable that values 1 if the buyer is a } \\
\text { natural person or a family and 0 otherwise. }\end{array}$ & $\begin{array}{l}\text { CNMV, press } \\
\text { The size of the firm }\end{array}$ \\
\hline $\begin{array}{l}\text { Target firm's market value at the end of the } \\
\text { outstanding shares by the close market price the }\end{array}$ & $\begin{array}{l}\text { CNMV, Annual } \\
\text { Reports Stock Market }\end{array}$ \\
\hline
\end{tabular}




\begin{tabular}{|c|c|c|c|}
\hline & $\begin{array}{l}\text { last day of the previous year (in thousands of } \\
\text { millions euros) }\end{array}$ & Bulletin & \\
\hline Industry & $\begin{array}{l}\text { Dummy variable that values } 1 \text { if the target firm } \\
\text { belongs to a specific industry (Basic Materials, } \\
\text { Industry and Construction, Consumer Goods, } \\
\text { Consumer Services, Petrol and Power, Real Estate) } \\
\text { and } 0 \text { otherwise. }\end{array}$ & $\begin{array}{l}\text { Stock } \\
\text { Bulletin }\end{array}$ & Market \\
\hline
\end{tabular}

\subsection{Regression analysis}

Using an ordinary least squares regression, where the dependent variable is the PB premium measured as a percentage of the targets' firm stock market value (PB), we test our hypotheses with the proxy variables put forward in order to obtain which ones could explain the variability of these premiums. ${ }^{17}$

$$
\begin{aligned}
P B_{i}=\beta_{0} \text { constant } & \left.+\beta_{1} \text { size of control of the buyer }+\beta_{2} \text { (size of control of the buyer) }\right)^{2} \\
& +\beta_{3} \text { size of control of the largest shareholder (excluding the buyer) } \\
& +\beta_{4} \text { natural person or family }+\beta_{5} \text { performance }+\beta_{6} \text { size of the firm } \\
& ++\sum_{j=7}^{12} \beta_{j} \text { industries }_{J}
\end{aligned}
$$

The results are shown in Table $6 .{ }^{18}$

Table 6. Results of the Ordinary Least Squares Regression

\begin{tabular}{lc}
\hline Dependent variable: Private benefits premiums x Block size \\
\hline Constant & $\begin{array}{c}-0.0093^{* * *} \\
(-4.79)\end{array}$ \\
\hline \multirow{2}{*}{ The size of control of the buyer } & $\begin{array}{c}0.0274^{* *} \\
(2.16)\end{array}$ \\
\hline \multirow{2}{*}{ (The size of control of the buyer) ${ }^{2}$} & $\begin{array}{c}-0.0586^{* *} \\
(-2.38)\end{array}$ \\
\hline
\end{tabular}

\footnotetext{
${ }^{17}$ Our sample is made up of 54 operations for 35 different target firms, once the outliers are removed. We consider outliers those PB values below the first quartile minus 1.5 times the interquartile rank or above the third quartile plus three times the interquartile rank. Of these 35 target firms, 25 have been affected by only one deal, 6 by two, 2 by three, 1 by four and 1 by five deals. This characteristic of our sample led us to discard the use of panel data techniques. Note that Petersen (2009) when making a survey of different methods used in the empirical literature to estimate standard errors in finance panel data sets only include papers that report at least five observations in each dimension, e.g. firms and years.

${ }^{18}$ Given the characteristics of our sample, described in the previous footnote, we believe that the use of clustered errors by firms would not be really necessary in our case. Anyway, we have re-estimate the regression with clustered errors by firm, and the standard errors obtained are quite similar to Huber-White standard errors, as we expected. As a consequence, all the estimated coefficients that are statistically significant in table 6 remain significant when clustered errors are used.
} 


\begin{tabular}{|c|c|}
\hline $\begin{array}{l}\text { The size of control of the "other large } \\
\text { shareholder" }\end{array}$ & $\begin{array}{l}0.0058 * * * \\
(2.91)\end{array}$ \\
\hline Identity of the buyer: natural person or family & $\begin{array}{c}0.0008 \\
(0.67) \\
\end{array}$ \\
\hline Performance & $\begin{array}{l}0.0001 \\
(0.21)\end{array}$ \\
\hline The size of the firm & $\begin{array}{c}0.0004^{* * *} \\
(3.98)\end{array}$ \\
\hline Industry & Yes \\
\hline $\begin{array}{l}\mathbf{F} \\
\text { p-value }\end{array}$ & $\begin{array}{c}4.31 \\
0.000\end{array}$ \\
\hline Adj. $R^{2}$ & 0.4001 \\
\hline Number of Observations & 54 \\
\hline
\end{tabular}

The results show that, according to our first hypothesis, there is a nonlinear relationship between the size of control (measured by the previous stake and the control block bought) and the size of PB, such that the higher the size of the final stake, the higher the size of PB is, as Weifeng et al. (2008) also find for the Chinese case. This relationship happens till a size of a maximum stake, around $26 \%$ of the equity on average, where the buyer would begin to have negative incentives to consume more PB (shown by the significant negative sign of the variable "the size of control of the buyer squared”). ${ }^{19}$

With regard to the other variable of the control structure that might be related to the size of $\mathrm{PB}$, the size of control of the largest controller (who is not the buyer), we find that it is significant with a positive sign. So hypothesis 3 seems to be supported in this sample, country and period. The explanation would be that instead of competing for the benefits, the buyer and the other largest shareholder support or consent each other the extraction of PB the higher is the stake of the other large shareholder. Conversely,

\footnotetext{
${ }^{19}$ We have calculated the value that maximizes the PB using the values of the coefficients of "The size of control of the buyer" and "(The size of control of the buyer) $)^{2}$ obtained in a regression made only with these two variables. The result is $26 \%$ of the equity.
} 
the lower is the stake of the largest shareholder who is not the buyer, the lower the control rents extraction by the buyer. So it appears that the shareholder structure affect the possibility of extracting control rents. This result seems to be in line with the one of Faccio et al (2001), who find that in East Asia the other large shareholder colludes in the expropriation from the minority shareholders. Nevertheless, the opposite sign is find in Weifeng et al., 2008 for Chinese firms.

Besides, we find that, although with a small impact, the size of the firm is significant in the regression with a positive sign (hypothesis 5a). So it seems that it is easier to get PB in larger firms because they are more difficult to monitor. The same result is found in Weifeng et al. (2008) and the contrary in the sample of the USA firms in Alburquerque and Schroth (2010) and for the Italian case in Massari et al. (2006) where the higher supervision made by regulators, media and analysts might be limiting the extraction of PB.

In relation to the variables that are not significant, we find that neither the performance, that it is significant for the USA case (Barclay and Holderness, 1989; Alburquerque and Schroth, 2010), nor the identity of the buyer are linked to the variability of $\mathrm{PB}$ in our sample. Those reasons that would give a positive effect when the buyer is a family (a higher expropriation from buyers) could be compensating the effect of the reasons (the family reputation) that would result in a lower expropriation of minority shareholders.

Concerning the significance of our regression model, the F-test shows that they are statistically significant, that is, that our models compared with models with no 
predictors improve the fit. ${ }^{20}$ At the same time, the check of residuals supports the validity of the results given to the coefficients. ${ }^{21}$

\section{Conclusions}

Buying a block of shares in the Stock Market not only provides a financial benefit but the possibility of gaining control as well. If this is indeed the case, the block would be a control block and it would involve a number of rents that only would enjoy the owner of the block, so these rents are considered private benefits. Taking a sample of control transactions made in the Spanish Stock Market between 1990 and 2016, the results show that, in median, there are no $\mathrm{PB}$ in this economy, contrary to what is generally found in most of the countries, which show positive values. Therefore, this result suggests that the Spanish stock market does not detect that the market for partial corporate control carried out by block transactions is inefficient in the allocation of financial resources as the buyers, in median, seem not to increase the use of firm resources for private uses in relation to the previous block owners. Nevertheless, they could be disguised in non-pecuniary benefits.

Comparing this result to previous papers that studied block transactions for the Spanish economy, Fernández and García (2000), on the one hand, showed null PB and Dyck and Zingales (2004), on the other hand, in their cross-country analysis, obtained a premium of $4 \%$ for the Spanish economy (represented by 5 firms where block transactions sizes are equal to or greater than 10 per cent). It appears that having a wider perspective of the market for partial control, without limiting the size of the control block transactions, allows private costs (negative private benefits) to emerge. Besides,

\footnotetext{
${ }^{20}$ When we test the models where PB are separated into positive and negative ones, we find that these models are not significant.

${ }^{21}$ Robust (Huber-White) standard errors can deal not only with heterokedasticity but also with some concerns about non-normality of the residuals. Either way, we can not reject the null hypothesis that residuals match a normal distribution (Jarque-Bera test $=3.365$ with a p-value $=0.186)$.
} 
this is an example of how individual country analysis gives different results in relation to cross-country analysis.

For our sample and period, we find that the main variables that explain in a significant way the variability of the PB are linked to controlling shareholders of the target firm. On the one hand, the buyer, whose controlling stake (that takes into account its previous position in the equity of the firm) shows a non linear relationship with the $\mathrm{PB}$, as the theoretical literature puts forward. Specifically, we find that once the buyer has achieved around $26 \%$ of the equity, the higher the block, the lower the extraction of PB. So it seems that large stakes would create incentives for the buyer for not consuming increasing sizes of PB in order not to pay higher shares of PB at the its own cost.

On the other hand, we find a significant impact from the largest controller who is not the buyer. Our results suggest that its behaviour could not be competing for the benefits with the buyer, or just restraining its private consumption, but supporting or consenting each other the higher its stake is. This result supports the theoretical models that states that the more unequal are the stakes of the controlling shareholders, the less contestability is the control and the more easier to extract PB.

Finally, in addition of the control structure of the target firm, the size of the firm seems to affect the consumption of $\mathrm{PB}$, although to a limited extent. 


\section{References}

Albuquerque, R. and Schroth, E. (2010). “Quantifying private benefits of control from a structural model of block trades”. Journal of Financial Economics, 96(1), 33-55.

Arregle, J. L., Hitt, M. A., Sirmon, D. G., and Very, P. (2007). The development of organizational social capital: Attributes of family firms. Journal of management studies, 44(1), 73-95.

Barak, R. and Lauterbach, B. (2011). "Estimating the private benefits of control from partial control transfers: Methodology and evidence”. International Journal of corporate governance, 2(3-4), 183-200.

Barclay, M. J. and Holderness, C.G. (1989). "Private benefits from control of public corporation”. Journal of Financial Economics, 25 (2), 371-395.

Bebchuk, L. A. (1994). "Efficient and Inefficient Sales of Corporate Control", The Quarterly Journal of Economics, 109(4), 957-993.

Bennedsen, M. and Wolfenzon, D. (2000). "The balance of power in closely held corporations”. Journal of financial economics, 58(1), 113-139.

Berle, A. A. (Jr.). (1958). “Control” in corporate law”. Columbia Law Review, 58 (8), $1212-1225$.

Berle, A.A. (Jr.) and Means, G.C. (1932). The Modern Corporation And Private Property. Nueva York: MacMillan.

Bethel, J. E., L. Porter and T. Opler. (1998). "Block Share Purchases and Corporate Performance”. The Journal of Finance, 53 (2), 605-634.

Bloch, F., Hege, U. (2003). Multiple shareholders and control contests. Unpublished manuscript. https://mpra.ub.uni-muenchen.de/42286/1/MPRA_paper_42286.pdf

Bolton, P.and Thadden, V. (1998). “Blocks, liquidity, and corporate control”. The Journal of Finance, 53(1), 1-25. 
Burkart, M., Gromb, D. and Panunzi, F. (1998). "Block premia in transfers of corporate control”. London: London School of Economics (Financial Markets Group, Discussion paper $\mathrm{n}^{\circ}$ 286).

Burkart, M., Gromb, D.and Panunzi, F. (2000). "Agency Conflicts in Public and Negotiates Transfers of Corporate Control", The Journal of Finance, 55(2), 647-667.

Carvalhal, A. and Subrahmanyam, A. (2007). "Dual-class premium, corporate governance, and the mandatory bid rule: evidence from the Brazilian stock market”. Journal of Corporate Finance, 13(1), 1-24.

Corbetta, G., and Salvato, C. (2004). Self-serving or self-actualizing? Models of man and agency costs in different types of family firms: A commentary on "comparing the agency costs of family and non-family firms: Conceptual issues and exploratory evidence”. Entrepreneurship Theory and Practice, 28(4), 355-362.

Demarchi, M. and T. Foucault. 1998. "Equity trading systems in Europe”. Annnales d'Economie et de Statistiques, 60, 73-115.

Demstez, H. and Lehn, K. (1985). “The Structure of Corporate Ownership: Causes and Consequences”. Journal of Political Economy, 93(6), 1155-1177

Doidge, C. (2004). "US cross-listings and the private benefits of control: evidence from dual-class firms”. Journal of financial economics, 72(3), 519-553.

Dyck, A. and Zingales, L. (2004). "Private benefits of Control: An international Comparison”. The Journal of Finance, 59 (2), 537-600.

Faccio, M., Lang, L. H., \& Young, L. (2001). “Dividends and expropriation”. American Economic Review, 91(1), 54-78.

Fama, E.F. and Jensen, M.C. (1983). “Separation of Ownership and Control”. Journal of Law \& Economics, 26 (2), 301-325.

Fernández-Blanco, M. and García, C.J. (2000). “La compra de volúmenes significativos de acciones en el mercado español”. Investigaciones Económicas, 24 (1), 237-267. 
Gomes, A., Novaes, W. (2001). "Sharing of control as a corporate governance mechanism”, PIER Working paper 01- 029, University of Pennsylvania Law School.

Gregoric, A. and Vespro, C. (2009). "Block trades and the benefits of control in Slovenia”. Economics of Transition, 17(1), 175-210.

Grossman, S. J. and Hart, O. D. (1980), "Takeover bids, the free-rider problem, and the theory of the corporation", The Bell Journal of Economics, 11(1), 42-64.

Hoffmeister, J. R. and Dyl, E.A. (1981). "Predicting Outcomes of Cash Tender Offers”. Financial and Management, 10, 50-58.

Isakov, D., and Weisskopf, J.-P. (2014). “Isakov, D., \& Weisskopf, J. P. (2014). Are founding families special blockholders? An investigation of controlling shareholder influence on firm performance. Journal of Banking \& Finance, 41, 1-16.

Jensen, M.C. and Meckling, W.H. (1976): "Theory of the Firm: Managerial Behaviour, Agency Costs, and Ownership Structure”. Journal of Financial Economics, 3 (4), 305-360.

Johnson, S., La Porta, R., Lopez-de-Silanes, F. and Shleifer, A. (2000). “Tunneling”. American Economic Review, 90 (2), 22-27.

Lease, C. R., McConnell, J. J. and Mikkelson, W. H. (1983). "The market value of control in the publicly-traded corporation”. Journal of Financial Economics, 11, 439 $-471$.

Massari, M., Monge, V. and Zanetti, L. (2006). "Control premium in legally constrained markets for corporate control: The Italian case (1993-2003)”. Journal of Management and Governance, 10(1), 77-110.

Maury, B., \& Pajuste, A. (2005). “Multiple large shareholders and firm value”. Journal of Banking \& Finance, 29(7), 1813-1834. 
Mikkelson, W. H. and H. Regassa. (1991). "Premiums paid in block transactions". Managerial and Decision Economics 12(6), 511-517.

Mikkelson, W. H. and M. M. Partch. 1985. "Stock Price Effect and Costs of Secondary Distributions”. Journal of Financial Economics, 14, 165-194.

Muravyev, A., Berezinets, I. and Ilina, Y. (2014). "The structure of corporate boards and private benefits of control: Evidence from the Russian stock exchange”. International Review of Financial Analysis, 34, 247-261.

Nenova, T. (2003). "The value of corporate voting rights and control: a cross-country analysis”. Journal of Financial Economics, 68, 325-351

Nicodano, G. and Sembenelli, A. (2004). "Private benefits, block transaction premiums and ownership structure”. International Review of Financial Analysis, 13(2), 227244.

OECD (2009). “Antitrust issues involving minority shareholding and interlocking directorates” Directorate for Financial and Enterprise Affairs, Competition Committee DAF/COMP(2008)30.

Park, Y. W., Selvili, Z. and Song, M. H, (2008).”Large outside blockholders as monitors: Evidence from partial acquisitions”. International Review of Economics and Finance, 17(4), 529-545.

Pérez-Soba, I., Márquez-de-la-Cruz, E., and Martínez-Cañete, A. R. (2018). Further empirical evidence on block transactions below the MBR: the Spanish market. The European Journal of Finance, 24(14), 1224-1251.

Petersen, M. A. (2009). “Estimating Standard Errors in Finance Panel Data Sets: Comparing Approaches”, The Review of Financial Studies, 22 (1), 435-480.

Rydqvist, K. (1992). "Takeover Bids and the Relative Prices of Shares That Differ in Their Voting Rights,” working paper, Stockholm School of Economics. 
Shleifer, A. and Vishny, R. W. (1986). "Large Shareholders and Corporate Control", Journal of Political Economy, 94 (3), 461-488.

Shleifer, A., \& Vishny, R. W. (1997). “A survey of corporate governance”. The journal of finance, 52(2), 737-783.

Trojanowski, G. (2008). “Equity block transfers in transition economies: Evidence from Poland”. Economic Systems, 32(3), 217-238.

Volpin, P. (2002). "Governance with Poor Investor Protection: Evidence from Top Executive Turnover in Italy". Journal of Financial Economics, 64, 61-90.

Walkling, R. A. (1985). "Predicting Tender offer Success: A Logistic Analysis". Journal of Financial and Quantitative Analysis 20 (4), 461-478.

Weifeng, H., Zhaoguo, Z., and Shasha, Z. (2008). “Ownership structure and the private benefits of control: an analysis of Chinese firms”. Corporate Governance: The international journal of business in society, 8(3), 286-298.

Yermack, D. (2006). "Flights of fancy: Corporate jets, CEO perquisites, and inferior shareholder returns”. Journal of Financial Economics, 80(1), 211-242.

Zingales, L. (1995). "Insider ownership and the decision to go public". The review of economic studies, 62(3), 425-448. 


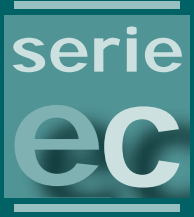

\section{I vie}

Guardia Civil, 22 - Esc. 2, 1 음

46020 Valencia - Spain

Phone: +34 963190050

Fax: +34 963190055

Website: http:/ / www.ivie.es

E-mail: publicaciones@ivie.es 